\title{
The Evaluation of Integrated and Holistic Education System (Ihes) Program in Gema Nurani Integrated and Holistic Islamic Elementary School, Bekasi, West Java
}

\author{
Indra Setiawan ${ }^{*}$, Madhakomala, Bedjo Sujanto \\ Department of Education Management, Universitas Negeri Jakarta, Indonesia
}

Received July 9, 2019; Revised September 9, 2019; Accepted September 16, 2019

Copyright $\bigcirc 2019$ by authors, all rights reserved. Authors agree that this article remains permanently open access under the terms of the Creative Commons Attribution License 4.0 International License

\begin{abstract}
This study aims to evaluate design, installation, process, outcome, benefit and cost in implementation of Integrated and Holistic Educational System (IHES) model in Gema Nurani Integrated and Holistic Islamic Elementary School, Bekasi, West Java. This study was conducted by using descriptive evaluative research with Discrepancy evaluation model. Data was collected through the result of interview, observation and documentation validated through Focus Group Discussion (FGI) activity. The result of study showed that: 1) The aspect of Design in implementation of IHES model in Gema Nurani Integrated and Holistic Islamic School, Bekasi, West Java has been based on IHES program owned by that school. 2) The aspect of Installation in implementation of IHES model had been completed by Standard of IHES Implementation in school which consist of standard components, namely: 1. Material Mastery, 2. Learning Media, 3. Fund Arrangement, 4. Arrangement and Determination. 3) Aspect of Process in implementation of IHES Model has not been in accordance with established standard particularly in standard component of the process in implementing IHES model, that is, there is no special laboratory particularly for Science subject. 4) The aspect of Outcome in implementation of IHES model has been in accordance with established standard. 5) The aspect of Cost and Benefit Analysis in implementation of IHES model in Gema Nurani Integrated and Holistic Islamic School, Bekasi, West Java has been in accordance with established standard. Therefore, infrastructure and training for all school members still need to be added to implement IHES model in Gema Nurani Integrated and Holistic Islamic School, Bekasi, West Java.
\end{abstract}

Keywords IHES Model, Evaluation, Discrepancy Model

\section{Introduction}

Integrated and holistic education is an effort to prepare elementary school students to become graduates who are equipped for the life on the earth and afterlife. As mandated in Act No.20 year of 2003, article 1, clause (1) and (2), that Education is conscious and planned effort to realize learning atmosphere and learning process in order that students develop their self potency actively to has religious spiritual power, self control, personality, intelligence, lofty moral, and skill needed by themselves, society, state and nation. National education is education which is based on Pancasila and 1945 Constitution of The Republic of Indonesia which rooted in religious values, national culture of Indonesia and responsive to the demand of era change.

By implementing IHES model, it is expected that students acquire learning in academic, attitude and Islamic education, so beside mastering academic aspect in school, students also will have attitude which is in accord with Islamic tenet and also for prepare themselves for the life for ever and hereafter. The availability of this IHES model help students to become smart in academic, has polite attitude and capable to apply the content in Quran given by their teachers. Therefore, this IHES model is absolutely available as means to maximize academic potential, shape attitude and character and inculcate the values of Quran and Sunnah. Another advantage is that learning is integrated with the values contained in Quran and Sunnah and it can be done as school effort to shape students' character in accord with Quran and Sunnah.

Gema Nurani Integrated and Holistic Islamic School, Bekasi, West Java is the one and only school in Bekasi even in Indonesia which use IHES model as educational model in school, the implementation of IHES model become means to improve IMTAQ and IPTEK in Gema Insani Integrated and Holistic Islamic Elementary School, 
Bekasi, West Java because according to researcher's tentative observation, there is still discrepancy between outcome and goal of predetermined program.

Based on study background above, the aim of this study is to evaluate design, installation, process, outcome and cost and benefit analysis in implementation of IHES model in Gema Nurani Integrated and Holistic Islamic Elementary School, Bekasi, West Java.

\section{Materials and Methods}

The policy issued by Department of Education through School Based Management (SBM) enable school to do management fully in accord with the needs of school environment. Through that policy, school is given autonomy right to manage school by using education model suitable with the needs of surrounding community and also to keep up with era development. To produce competent graduates, school needs to equip their students among others through academic, shaping character through attitude judgment, Islamic values for prepare themselves for the life in ever and hereafter.

In addition, it can be understood that school today can shape students' character which is appropriate with religious values. It is expected that the religious activity done in school can form students' character to become more religious. The religious activity integrated into national curriculum learning can be so meaningful for students.

Besides national curriculum learning, students also learn about Islam in accord with learning material done in class. According to (Griffin, 2014), in The Heart of Holistic Education journal: The Heart of Holistic Education is expressed through the experience of its innovative models. The heart of holistic education lies in thirteen supporting core essences, arranged into six related groupings (a) ancient wisdom, consciousness, and peace; (b) culture and arts; (c) biophilia and biophilic design of the built environment; (d) emerging industries; (e) parents, teachers and administrators; (f) humanistic and spirituality, upon which this approach may evolve. (Melancona \& Hendry, 2015) In contrast, integrated schooling would change this way of thinking, would prevent history from repeating itself in yet another civil war, and would heal these divisions to create one, unified, American nation. Integration was the only way to ensure that all Americans, both blacks and whites, had access to an equal education.

Literally, holistic learning is defined as learning which maximize all aspects in students. In addition, integrated curriculum is curriculum which combine several disciplines through integration of content, skill and attitude (Wolfinger, 1994). The rational of that integration among others are caused by the following:

1. Many problems and experiences (including learning experience) is interdisciplinary, so it needs multi-skill to understand, learn and solve them.
2. There is demand for high collaborative interaction in solving various problems.

3. Ease children to make relation among schemata and transfer among context.

4. Efficiency.

5. There is demand for children's high involvement in learning process.

The activity in holistic education is to determine the goal to build holistic human, should use holistic education concept, as mentioned in Education 2000: A Holistic Perspective agreement. The essence of that agreement is how educational system can:

1. Teach students about awareness that each aspect in life is interconnected so they can live the life productively, peaceful, and continuously because each individual's action will effect on his/her environment.

2. Educate all aspects of human dimension.

3. Appreciate that each human has his/her strength.

4. Educate to think holistically, which comprise intuition, context, creativity and physical aspect.

5. Give conducive learning environment, because learning is an active process which is intrinsically motivated, support and excite human spirit.

6. Use holistic curriculum (interdisciplinary) which integrates community with global perspective.

From some explanations mentioned above, it can be concluded that integrated and holistic education is education which give learning experience which ease students in learning because it integrates multi disciplines and also educate all aspects in students. This advantage is used give new experience which can maximize self potency particularly 'the soul" in students which make students to become better individual.

Before discussing deeply about evaluation, according to (Stufflebeam \& Shinkfield, 2007) state as follow: Evaluation is the systematic assessment of the worth of merit of an object. Evaluation's roof term, value, denotes, that evaluations essentially involve making value judgment. Accordingly, evaluations are not free. They need to be grounded in some defensible, set of guiding principles of ideals and should determine that evaluands standing against these values. Furthermore, Stufflebeam complete definition of evaluation as follow: Evaluation is the systematic assessment of an object's merit, worth, probity. feasibility, safety, significance and or equity. It see the values referenced in this definition as particularly important in a free and democratic society; but also acknowledge that might have included additional values. While according to (Yarbrough, Shulha, Hopson, \& Caruthers, 2011), define evaluation as 'evaluation is systematic investigation of the value, importance, or significance of something of someone defined along dimensions.' So evaluation become one important component in a program. From the three definitions above 
(Stufflebeam \& Shinkfield, 2007), (Yarbrough et al., 2011) it can be concluded that program is value consideration, systematic assessment and one important component in a program.

Whereas the definition of program in general is understood as a plan. (Arikunto, 2010) assert that the definition of program is as follow: Program is an unit of activity which is a system, namely the activity done not only once but continuously. Program involve a group of people in an organization. Next, (McDavid \& Hawthorn, 2006) defines program as follow: Program defined as a group of related activities that is intended to achieve one or several objectives. Programs are means-ends relationship that are designed and implemented purposively. They can very a great deal in scale. Furthermore, (Owen, 2006) defines program as follow: Program is an intentional effort at change in which, in addition to its effect on participants, may have secondary effect on the context, within which the program is located, for example, an organization or more diverse socio-cultural setting. Refer to the three definitions above, it can be understood that program is interconnected activity in organization. The outcome of program implementation for each unit also should follow the prevailed system in that organization. The implementation of program will effect on participants, so it can be implemented purposively. Such steps are done to achieve several objectives of program evaluation, so it should be initiated by discussion about the definition of evaluation according to the experts. In general, the definition of evaluation is understood as an activity to gather information in order to determine a policy for the next program to follow-up. According to (Steele, 2010) defines program evaluation as follow: Program evaluation is a process of judging (or a judgment as to) the worth of value of a program. This judgment is formed by comparing evidence as to what the program is with the criteria as to what the program should be.

The above definition give description that there are three important points in evaluation activity namely: judging, collecting evidences and deciding the result.

Meanwhile, (Rossy, Lipsey, \& Freeman, 2006) define program evaluation as follow: Program evaluation is the use of social research methods to systematically investigate the effectiveness of social intervention programs in ways that are adapted to their political and organizational environments and designed to inform social action in way to improve conditions.

Meanwhile, (Wirawan, 2016b) say. In education, program evaluation refers to the sets of activities involved in collecting information about the operation and effects of policies, program, curriculum, sources and educational software and other instructional materials.

Based on the experts' opinion above, it can be understood that evaluation investigate systematically a program and regulate and gather information about a program (Steele, 2010) (Rossy et al., 2006) (Wirawan, 2016b) Discrepancy Evaluation Model is developed by Malcolm Provus Model. This evaluation emphasize the discrepancy in program implementation. Evaluator describe the discrepancy between performance standard with real performance which had been implemented (Arikunto, 2010). As for the stages which should be implemented in discrepancy evaluation model according to (Wirawan, 2016a) are: 1) Plan evaluation by using discrepancy model, determine the informant needed to compare the real implementation with standard which define the performance of object evaluation, 2) Asses the performance of evaluation object which comprise program implementation, quantitative and qualitative results, 3) Identify the discrepancy between implementation standard with the implementation result of real evaluation object and determine the gap ratio, 4) Determine the discrepancy by making changes toward implementation of evaluation object.

(Provus, 1971) discrepancy model evaluation has the stages of development as follow: 1. Design and refer to the nature of program, its objective, students, staff and other resources required for the program, and the actual activities designed to promote attainment of the objectives. The program design that emerges becomes the standard against which the program is compared in the next stage, design that emerges becomes determining whether an implemented program is congruent with its implementation plan, 2. Process, in which evaluator serves in a formative role, comparing performance with standards and focusing on the extent to which the interim or enabling objectives have been achieved, 3. Product is concerned with comparing actual attainment against the standards (objectives) derived during stage 1 and noting the discrepancy (Clare Rose \& Glenn F. Nyre, 1977:15).

Based on some opinions above about the definition and component of stages in implementing evaluation by using Discrepancy Model, then it can be understood that discrepancy evaluation model is the type of evaluation model done by measuring or describing between standard used with real condition in implementing a program. The component which should be noticed or become procedure in implementing Discrepancy Model according to Provus (in (Wirawan, 2016a)) comprise the stages as follow: 1) Design is the stage of activity to formulate goal, process, and allocation of resource in doing activities to achieve the determined goal, 2) Installation is design used as standard in order to consider the steps in program operational, 3) Process is evaluation activity centered to the effort to obtain data about the progress of program, in order to determine whether program had been in accord with the expected goal, 4) Product is evaluation to determine whether the goal of program had been achieved, 5) Cost and benefit analysis is analyze the outcome obtained compared with the cost expended.

The evaluation model which will be used in this study is Discrepancy Evaluation Model (DEM). Evaluation is 
focused to find out the discrepancy or mismatch between implementation of IHES model program with IHES model designed by school. Knowing this discrepancy can give input to improve the implementation of IHES model program in Gema Nurani Integrated and Holistic Islamic School, Bekasi, West Java.

This study cannot be separated from earlier study conducted by (Forbes, 2003) The authors certainly saw these procedures as interdependent, often as two faces of the same coin. While each author (and many forms of holistic education) has slightly different versions of these procedures, they generally have the following characteristics in common:

1. The exercise of good judgment.

2. The ability to be free.

3. The ability to discover and refine values.

4. Meta-learning.

5. Social-ability.

According to (Rathnam, 2013) in his journal Whole Teachers: A Holistic Education Perspective on Krishnamurti's Educational: (Forbes, 2003) analyzed the life of six individuals who are generally considered to have laid the foundations of holistic education: (Rathnam, 2013), Forbes states that these six founding fathers of holistic education felt that teachers' self-development, which revolved around the development of virtues, morals and religiousness to be - an essential element in the students' education (p.45). Forbes's notion of religiousness can also be defined as spirituality. Four participants (teachers) were interviewed from Oak Grove School, and alternative, holistic school founded by Krisnamurti in 1974. This inquiry probed into teachers' thinking, teachers' lives, teachers' inner lives, teachers' contemplative practices, teachers' calling/vacation and teachers' pedagogy. Findings of this inquiry reveal the awareness that exist among the participants with regards to their understanding of Krisnamurti's educational philosophy and the way in which this philosophy has shaped their Krisnamurti's philosophy has certainly had an impact on the participant's wholeness, Krisnamurti was never interested in imposing his philosophy on the teachers to think in a narrow groove. Rather, he challenged them to arrive at wholeness or a holistic approach toward living by their own volition, by putting aside all philosophy, including his own. The research points toward the possible ways in which wholeness can be developed using: innate wisdom (teachers' inner life, teachers' calling); wisdom gained through experiencing life (teachers' life, teachers' thinking); wisdom gained through their teaching experience (teachers' pedagogy) and wisdom gained through practices that bring harmony to the mind, body and spirit (teachers' contemplative approaches).
This study is qualitative descriptive with Discrepancy Evaluation Model. It because this study try to do evaluation activity and describe study data in the form of explanation and statement about implementation of IHES model in Gema Nurani Integrated and Holistic Islamic School, Bekasi, West Java toward IHES model itself. This study was conducted in Gema Nurani Integrated and Holistic Islamic Elementary School, Bekasi, West Java, address in Jl. Raya Kaliabang Tengah No.75B, Kaliabang Tengah, North Bekasi, Bekasi City, West Java 17125. Whereas, this study was conducted in February 2016 until March 2018.

Data collection technique used in this study comprise: 1 ) In-depth interview with The Head of Yayasan, Headmaster, teachers, staffs, students, students' parent, and alumni. 2) Observation to obtain information about activity process done based on IHES model consisting of plan activity, teaching and learning activity, religious activity, parents meeting. 3) Documentary study to obtain information of program implementation comprising IHES model, curriculum, RPP, detail of registration fee and tuition, infrastructure, data on students and students' parent. 4) Focus Group Discussion to validate data obtained based on interview, observation and documentary study.

The stages in doing data analysis in this study comprise: 1) Data collection, 2) Data reduction, 3) Data display, 4) Verification/ Conclusion. In stage of data collection, data was obtained from sources through interview, observation and documentary study. After collecting data, data reduction and data sorting was done in accord with its own category based on Discrepancy model comprising program design, installation, process and outcome. After data was reduced and sorted based on its category, the next stage is data display which arrange and present data, then conclusion was drawn or verification.

Data validity test was used in this study by using source triangulation technique. In this study, source triangulation was done by validating data obtained through interview, observation and documentary study through Focus Group Discussion activity. FGD activity will result in data on validated study result as material to hold discussion in evaluation research activity, through discussion result which present resource persons or informants including The Head of Yayasan, Headmaster, teachers, staffs, students, students' parent, and alumni.

\subsection{Paper Title}

The Evaluation Of Integrated And Holistic Education System (IHES) Program In Gema Nurani Integrated Islamic Elementary School, Bekasi, West Java.

Based on (Shi, 2015) research on integrated education model in college English teaching, Qinhuangdao Institute of Technology by making the scheme as follow: 


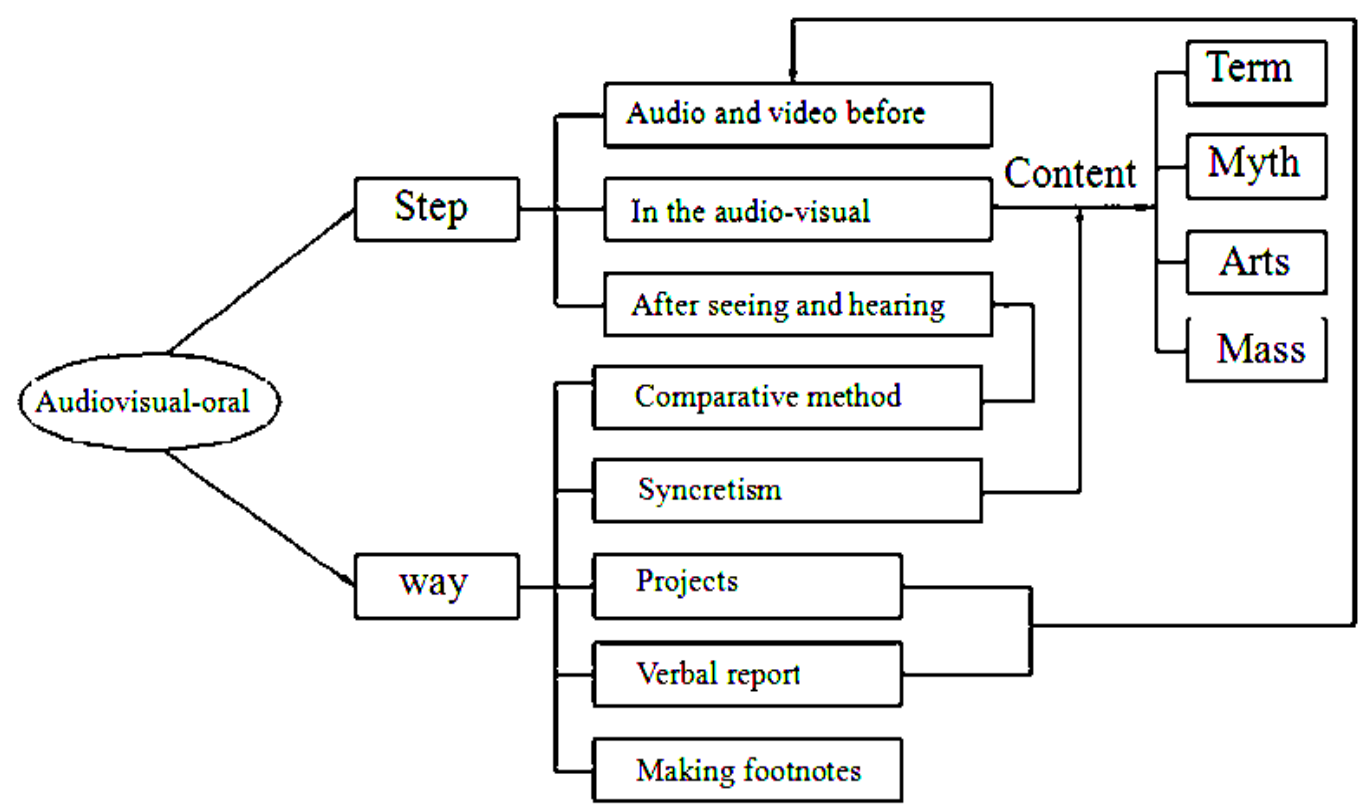

Figure 1. Integrated Education

Based on the scheme above:

1. Oral-audiovisual enter the part of step, namely:

a. Audio and video before

b. In audio-visual, the content consist of:
1) Term
2) Myth
3) Art
4) Mass

2. Way consist of several steps:

a. Comparison method

b. After seeing and hearing

c. Synchronization

d. Project

e. Verbal report

f. Making footnotes

According to the study above, that integrated and holistic education enable students to optimize all aspects in them particularly in learning which integrate all aspects started from audio, visual, art an also making footnote. Based on the study result above, integrated and holistic education is seen, in which teacher put aside their personal interest for their students and implement learning by using audio-visual and make footnote to synchronize learning in class. Each IHES model certainly has consequence in its application. However, if implementation of integrated and holistic education run maximally, it enable students to be good in academic, attitude and Islam religion tenets. The implementation of IHES model in Gema Nurani Islamic School, Bekasi, West Java has produced the graduates accepted in Public Junior High School because knowing the quality of earlier school. Not only excellent in academic but the graduates also excellent in Islam religion tenets because at least they memorize juz 30 in Quran. Besides, they grow the attitude to love Quran and slowly shape students' character to become better in accord with Islam religion tenets.

To implement that evaluation activity, it use an evaluation model with design to compare the implementation of program in field with established standard, namely by using discrepancy evaluation model. The discrepancy evaluation model gather information through the stages of component which comprise: 1) Design, 2) Installation, 3) Process, 4) Product and, 5) Cost and Benefit Analysis. Through that evaluation activity, it is expected that it will give an outcome which capable to see to what extent the achievement of IHES model implementation in Gema Nurani Integrated and Holistic Islamic School, Bekasi, West Java, and give follow-up of next policy to that program. 
Table 1. Comparison between conventional education system and IHES

\begin{tabular}{|c|c|}
\hline Conventional Education System & Integrated and Holistic Education System (IHES) \\
\hline - $\quad$ Focus is based on learning. & $\begin{array}{ll}- & \text { Focus on learning outcome: } \\
- & \text { Immersion and knowledge } \\
- & \text { Character building (Akhlaq) } \\
- & \text { Academic achievement } \\
\text { - } & \text { Application in life }\end{array}$ \\
\hline - $\quad$ Based on age & - $\quad$ Grade promotion depend on potency not age. \\
\hline $\begin{array}{l}\text { - Teaching and learning process is } \\
\text { conventional }\end{array}$ & $\begin{array}{ll}- & \text { Development program is based on tarbiyah process } \\
- & \text { Learning and teaching } \\
- & \text { Building process } \\
- & \text { Training process } \\
- & \text { Advising process } \\
- & \text { Consultation process }\end{array}$ \\
\hline 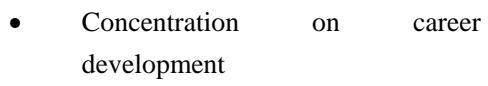 & $\begin{array}{l}\text { - Educational model is based on whole human development in life and career system } \\
\text { development. }\end{array}$ \\
\hline $\begin{array}{l}\text { - } \quad \text { Educational program is discrete and } \\
\text { separated. }\end{array}$ & $\begin{array}{l}\text { A continuous educational program with Qurani generation, nurturance development } \\
\text { program, preschool, elementary school, secondary school, high school, and alumni. }\end{array}$ \\
\hline $\begin{array}{l}\text { - } \quad \text { Secular program in moral and civic } \\
\text { awareness }\end{array}$ & $\begin{array}{l}\text { - Tarbiyah, daily tazkiah, weekly usrah, monthly qiyamulail, tamrin for each semester } \\
\text { programs, annually mukhoyyam program. }\end{array}$ \\
\hline $\begin{array}{l}\text { - } \quad \begin{array}{ll}\text { Partial human development } \\
\text { program }\end{array} \\
\end{array}$ & $\begin{array}{l}\text { - Development of whole human potency, intellectual, emotional, religious, physical } \\
\text { programs. }\end{array}$ \\
\hline $\begin{array}{l}\text { - } \quad \text { Partial and compartmented } \\
\text { curriculum development }\end{array}$ & $\begin{array}{ll}\text { - } & \text { Integrated and holistic curriculum development program in a whole } \\
\text { - } & \text { National Curriculum } \\
- & \text { International Curriculum } \\
- & \text { Coordination Curriculum } \\
- & \text { Extra Curriculum } \\
- & \text { Core Curriculum based on Quran and Sunah. }\end{array}$ \\
\hline $\begin{array}{l}\text { - The numbers of students, ratio of } \\
\text { teacher and student is } 1: 40\end{array}$ & - $\quad$ The numbers in small class, ratio of teacher and students is 1:20. \\
\hline $\begin{array}{l}\text { Partial assessment with } \\
\text { conventional children program }\end{array}$ & $\begin{array}{l}\text { - Continuous assessment process with special program for children in general, special } \\
\text { children, and gifted children. }\end{array}$ \\
\hline & $\begin{array}{l}\text { - Continuous development and assessment both in academic intelligence and character } \\
\text { building. }\end{array}$ \\
\hline
\end{tabular}

The analysis of review and result study in the aspect of design gives a perspective that in implementing IHES model program needs to give attention to the needs and goal which will be achieved. It should become one important foundation to operate a program. The review of this study result substantially had been tried to elaborate and collect information about that IHES model program. After the background and goal of program is determined, the aspect of plan become next step. It also expressed by Usman (2013) that in aspect of planning a program needs to decide the activity. Through that condition, it needs a foundation or background in running a program.

Based on result study and experts' opinion, it can be concluded that implementation of IHES model program had fulfilled the design component comprising background and goal, and standard in implementing IHES model program.

\section{Installation of IHES model program implementation}

The aspect of installation in implementing IHES model program in Gema Nurani Islamic School, Bekasi, West Java is mentioned in four standard components of IHES model implementation standard which has been set by Yayasan Asasi Indonesia.

The study result showed that the aspect of installation in implementation of IHES model program in Gema Nurani Integrated Islamic School, Bekasi, West Java has been completed by four (4) component standard as follow: 1) 
Material Mastery, 2) Learning Media, 3) Fund Arrangement, 4) Arrangement and Determination. This result study give description that in implementation of IHES model program had been refer to established standard in IHES model program.

Similarly, Usman (2013) say that the determination of standard in a plan needs to rely on standard in order to consider effectiveness and efficiency, and oriented to the future. Therefore, from the rule aspect of implementing production and service unit program had referred to five standard components established by government.

This study result is in accord with the study conducted by (Widyastono, 2012) that implementation of holistic education in elementary school and secondary school level had been in accorded with used standard. Based on the study result, the experts' opinion and earlier study result, then it can be concluded that in aspect of installation in implementing IHES model program had fulfilled the standard in running the program.

Implementation of standard component of IHES program model in Gema Nurani Integrated and Holistic Islamic School, Bekasi, West Java emphasize the activities of Material Mastery, Learning Media, Fund Arrangement, Arrangement and Establishment of using infrastructure. The study result finding showed that the aspect of process in implementing IHES model program had not in accorded with standard component of the established program and arrangement and decision in using infrastructure.

In the aspect of program component standard, that implementation of IHES model program from management aspect, Human Resource and infrastructure arrangement has not been managed well. It showed in the result of FGD (Focus Group Discussion) conveyed by teachers as follow:

"learning depends on its material, if learning specifically take place in Science Laboratory and also in places surrounding school (fish pool, yard and trees), while for learning Bahasa now has not done in Language Laboratory because there is still reparation inside. (FGD result, 12 February 2019).

That result give description that the aspect of determine infrastructure usage had not been scheduled. Similarly, FGD result also conveyed by Headmaster as follow:

"IHES curriculum here is still refined, one of them is about the lack of facility in which Nature Laboratory is not available because in IHES mention the room (the yard which contain animals and plants). Nature and technology will be taught in Science Laboratory (INDRA SETIAWAN, 2018)

Based on FGD result and interview with Headmaster and teachers above, then implementation of IHES model program in Gema Nurani Integrated and Holistic Islamic School, Bekasi, West Java had not implemented the standard for running the program.

The aspect in outcome evaluation in implementation of IHES model program in Gema Nurani Integrated and Holistic Islamic School, Bekasi, West Java, refer to achieving the aim of IHES model program implementation. Based in the study result which state that in aspect of outcome in implementation of IHES model program that program had been in accorded with predetermined aim. It is showed one of them by some subjects which has been integrated with Islam religion tenets. The subjects in school not only learn religion (Islam), but national education by using local curriculum in school can be balanced. IHES comprise national education program, for example: RPP from national education added with IHES (Science is related to the verses of Quran). So students understand that everything learned has been arranged by Allah SWT (interview with classroom teacher, 2019). The finding of study showed that achievement of outcome evaluation is measured through achievement of predetermined aim. Therefore, in plan management concept to run the program of production and service unit has been in accorded with the aim in operating the program. Similarly, Husaini (2013) state that to achieve the aim, then there should be a plan in operating the program.

In addition, the realization in achieving maximal outcome also seen from collaboration activity between Gema Nurani Integrated and Holistic Islamic Elementary School, Bekasi, West Java with ADNY School, Malaysia as the pioneer of IHES model program, Integrated Islamic School Kota Damansara (IISKD) Malaysia, Madrasah Al Islamiyah Al Junied Singapore, Integrated and Assessment Board (IHAB) Malaysia, Centre for International Examination (CIE) of Al-Azhar University, Indonesia, Perguruan Ar Rafi Bandung, and active in educational movement in JSIT Indonesia. In addition, Gema Nurani Integrated and Holistic Islamic School, Bekasi, West Java also continuously conduct IHES training in ADNY School, Malaysia. Gema Nurani also collaborate with SMP Islam Terpadu Gema Nurani, Bekasi, West Java if SDIT graduates want to enter higher level school.

Through that collaboration activity, the goal of operating the program in aspect of collaboration with another school had been fulfilled. With collaboration between Gema Nurani Integrated and Holistic Islamic School, Bekasi, West Java with another school, then it can improve the implementation of IHES model program indirectly and also collaboration with another school. Based on the study result, it can be concluded that in aspect of outcome for implementing IHES model program, Gema Nurani Islamic School had been in accorded with predetermined aim.

The aspect of cost and benefit analysis in implementing IHES model program viewed from the outcome gained and cost expended for teaching and learning activity had not been in accorded with standard used in operating the program. It is seen from capital source used in implementation of IHES model program. Based on data from researcher that capital source generated from three (3) sources namely registration fee, school tuition and School Operational Cost fund. It also through the result of FGD by Headmaster, teachers, students' parent and staff that "every 
the date of 10 students should pay school tuition and there is dispensation for now. As for teachers' son or daughter there is dispensation and I would like to say thank. The amount is vary depends on teaching experience in school and the tenure. The informant 2: for registration (in the beginning of year) can be paid $2 \mathrm{x}$ for semester 1 and semester 2, and for school tuition can be paid in the date of 10 for each month. Thus, so far teaching and learning activity run well, similarly with incentive for teachers, staff, office boy (OB) and security guard run well without obstacle.

Through that result study, it needs plan and financial management and production which are worth to be considered in operating that program. Concerning financial resource management, Handoko (2003) say that financial management is important thing in implementing the function of management.

From the aspect of benefit, the quality of graduates shows enhancement of mean score in national school exam about 5\% for Bahasa Indonesia subject, 4\% for Math subject, and $5 \%$ for Science subject. Based on the study result above, then it can be concluded that in aspect of cost and benefit analysis, the implementation of IHES model in SDIT Gema Nurani, Bekasi, West Java, has been in accorded with standard and expectation.

\section{Conclusions}

Based on study result and discussion above, it can be concluded that:

1. The aspect of Design in implementation of IHES model in SDIT Gema Nurani, Bekasi, West Java based on background of program implementation and it is in accordance with IHES model program in SDIT Gema Nurani, Bekasi, West Java.

2. The aspect of Installation in implementation of IHES model in SDIT Gema Nurani, Bekasi, West Java has been completed by the standard of IHES model program in SDIT Gema Nurani, Bekasi, West Java which consist of standard components: 1) Material mastery, 2) Learning media, 3) Fund arrangement, 4) Arrangement and Determination of using infrastructure.

3. The aspect of Process in implementation of IHES model in SDIT Gema Nurani, Bekasi, West Java has not been in accordance with predetermined standard particularly in program standard component of teacher and staff' attitude, and infrastructure.

4. The aspect of Outcome in implementation of IHES model in SDIT Gema Nurani, Bekasi, West Java has been in accordance with established standard.

5. The aspect of Cost and Benefit Analysis in implementation of IHES model in SDIT Gema Nurani, Bekasi, West Java had been in accordance with established standard.

\section{Acknowledgements}

By uttering as high praise as the thankfulness of the presence of God Almighty, for all His grace and gifts to researchers, finally the researcher can complete the research entitled "The Evaluation Of Integrated And Holistic Education System (IHES) Program In Gema Nurani Integrated Islamic Elementary School, Bekasi, West Java, Indonesia.

The researcher realized that this research could be completed thanks to the support and assistance from various parties. Therefore, the researcher thanked all parties who directly or indirectly contributed to the completion of this research. In particular, the researcher expressed his gratitude to:

1. Prof. Dr. R. Madhakomala, M.Pd., As the Promotor of Universitas Negeri Jakarta (UNJ)

2. Prof. Dr. Bedjo Sujanto, M.Pd., as Co. Promotor, Universitas Negeri Jakarta (UNJ)

3. To Mr. Abdul Halim and Mrs. Wagiyatun, S.Pd., as parents, the researchers expressed their respect and gratitude that they always prayed for, provided support for the success and safety of researchers over the years.

4. The beloved Indri Dwi Astuti and Indra Kadarusman as the younger siblings and Andra Pratama Kadarusman and the late Almarhum Azka Afgansyah Kadarusman as nieces and nephews, the researchers offered love that always prayed for, provided moral and material support for the success and safety of researchers over the years.

\section{REFERENCES}

[1] Arikunto, S. (2010). Evaluasi Program Pendidikan. Jakarta: Bumi Aksara.

[2] Forbes, S. H. (2003). Holistic Education: Its Nature and Intellectual Precedents, Holistic Education, Inc. Portland.

[3] Griffin, C. (2014). Master of Arts from Prescott College in Education: Experiential Education, Published by ProQuest LLC, 2014, United States. The Heart Of Holistic Education: The Heart of Holistic Education Is Expressed through the Experience of Its' Innovative Models, UMI 155728.

[4] INDRA SETIAWAN. (2018). TRANSKRIP WAWANCARA KEPALA SEKOLAH. BEKASI.

[5] McDavid, J. C., \& Hawthorn, L. R. L. (2006). Program Evaluation and Performance Measurement: An Introduction to Practice. London: SAGE Publications.

[6] Melancona, K. R., \& Hendry, P. M. (2015). Listen to the voice of reason: The New Orleans Tribune as advocate for public, integrated education, Department of English, Mississippi College, Clinton, Mississippi, USA; School of Education, Louisiana State University, Baton Rouge, Louisiana, USA, Histo. 44, 293-315. Retrieved from 
http://dx.doi.org/10.1080/0046760X.2014.1002017

[7] Owen, J. M. (2006). Program Evaluation: Forms and Approaches. NSW: CMO.

[8] Provus, M. (1971). Discrepancy Evaluation Model, For Educational Program Improvement and Assesments. USA: McCutchan Publishing Coorporation.

[9] Rathnam, A. (2013). Educational Philosophy Doctor of Philosophy Department of Curriculum, Teaching and Learning, ISBN, University of Toronto . Whole Teachers: A Holistic Education Perspective on Krishnamurti'S, 978-0-499-.

[10] Rossy, P., Lipsey, M., \& Freeman, H. (2006). Overview of Program Evaluation. Journal of Social Education, 11, 1-2.

[11] Shi, Y. (2015). SHS Web of Conferences 01012 (2016) , Qinhuangdao Institute of Technology, Qinhuangdao, Hebei, China. Research on Integrated Education Mode in College English Teaching. https://doi.org/10.105 012 1/ 20151

[12] Steele, S. M. (2010). Developing a Concept of Program Evaluation. US: Pearson.

[13] Stufflebeam, D. L., \& Shinkfield, A. J. (2007). Evaluation Theory, Models and Applications. San Fransisco: Jossey Baa.

[14] Widyastono, H. (2012). Muatan Pendidikan Holistik Dalam Kurikulum Pendidikan Dasar dan Menengah, Pusat Kurikulum dan Perbukuan, Balitbang Kemdikbud. Pendidikan Dan Kebudayaan, 18(4).

[15] Wirawan. (2016a). Evaluasi: Teori, Model, Metodologi, Standar, Aplikasi dan Profesi. Jakarta: PT. Rajagrafindo Indonesia.

[16] Wirawan. (2016b). Evaluasi: Teori, Model, Metodologi, Standar Aplikasi dan Profesi. Jakarta: Rajawali Press.

[17] Yarbrough, Shulha, Hopson, \& Caruthers. (2011). Program Evaluation, Concepts and Practic. London: Sage Productions. 